Original Article

\title{
Red blood cell alloimmunisation and autoimmunisation in transfusion dependent beta thalassemics from Southern India
}

\author{
Mohammed Saleem E.K. ${ }^{1}$, Soundarya Mahalingam², Shamee Shastri ${ }^{3}$ \& Kamalakshi G. Bhat ${ }^{4}$ \\ ${ }^{1}$ Senior Resident, Department of Pediatrics, M ES Academy of M edical Sciences, Kerala University of Health Sciences, \\ Kerala, ${ }^{2}$ Associate Professor, ${ }^{4}$ Professor Department of Pediatrics, KM C, M angalore, M anipal University, \\ ${ }^{3}$ Associate Professor, Department of Immunohematology and Blood transfusion, KM C, Manipal University, Manipal.
}

\author{
Correspondence \\ Kamalakshi G. Bhat \\ Department of Pediatrics, KM C Hospital, Manipal University, Attavar, Mangalore - 575001. \\ E-mail : bhat_kamalakshi@yahoo.co.in, kamalakshi.bhat@manipal.edu
}

\begin{abstract}
The development of red blood cell (RBC) isoimmunization with alloantibodies and autoantibodies complicate transfusion therapy in multiply transfused thalassemia patients. We conducted a study to analyse the frequency in our population. Clinical and antibody profile from 55 multiply transfused thalassemic patients who were receiving transfusions were collected and analyzed prospectively. A commercially available 3 cell antigen panel was used for the antibody screening procedure. If antibody screening with the 3-cell antigen panel was positive, an extended 11-cell antigen panel was used for antibody identification in LISS (Low Ionic Strength Solution). All patients received blood matched for only $\mathrm{ABO}$ and $\mathrm{Rh}(\mathrm{D})$ antigens. A total of 55 transfusion dependent $\beta$ thalassemics were included in this study out of which $30(54.55 \%)$ were males and $25(45.45 \%)$ females with a male to female ratio of $1.2: 1$. Frequency of red cell alloimmunization in this study was found to be $1.8 \%$. None of the patients developed red cell autoimmunization. The alloantibody identified in the the patient who developed alloimmunisation was was anti-K. In conclusion, the transfusion of matched blood is essential for chronically transfused beta thalassemia patients in order to avoid alloimmunization.
\end{abstract}

Key words: alloimmunisation, beta thalassemia major, transfusion

\section{Introduction}

Treatment modalities for patients with beta thalassemia major include chronic transfusion therapy, iron chelation, splenectomy, and allogeneic hematopoietic transplantation. The goal of long-term transfusion support is to maintain the patient's hemoglobin at $9.5-10 \mathrm{~g} / \mathrm{dL}$, thus improving his or her well-being while simultaneously suppressing enhanced erythropoiesis. Although chronic blood transfusion is lifesaving, this is associated with complications like erythrocyte alloimmunization and autoimmunization and poses a major challenge for repeated transfusions in these patients. Allogeneic blood transfusion is a form of Access this article online Quick Response Code

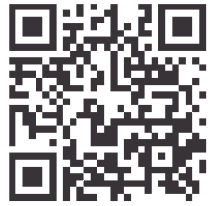
$t$ e $m$ p o r a $r y$ transplantation and this procedure introduces a multitude of foreign antigens and living cells into the recipient that persist for a variable period of time. A recipient who is immunocompetent often mounts an immune response to the donor antigens, resulting in various clinical consequences, depending on the blood cells and specific antigens involved. The factors responsible for alloimmunization are complex and involve antigenic differences on the red cell between the blood donor and the recipient; the recipient's immune status ; and the immunomodulatory effect of the allogenic blood transfusions on the recipient's immune system(1). Some alloantibodies are hemolytic and may cause, though not invariably, hemolytic transfusion reactions and limit the availability for further safe transfusions. Others are clinically insignificant. The frequency of alloimmunisation among thalassemics in India ranges from 3.79\% to $18.8 \%$ $(2,3,4)$ and across the world frequency ranges from $2.7 \%$ to $37 \%(5)$

Erythrocyte autoantibodies appear less frequently but they can result in clinical hemolysis and difficulty in cross matching of blood. Patients with autoantibodies may have a higher transfusion rate and often require 
immunosuppressive drugs, splenectomy or alternative options in treatment. $(6,7,8)$.

\section{Material and Methods}

This was a cross-sectional descriptive study conducted in Kasturba Medical College Hospital, Attavar, Mangalore from January 2011 to December 2011, after obtaining informed consent from the parents of all patients. Time bound Research Ethics Committee had approved the study. Study was conducted in 55 beta-thalassemia patients who were on regular blood transfusion.

Parents were interviewed and the transfusion records were examined for the details like, age of the patient, age at diagnosis and initiation of transfusion therapy, total number of blood units transfused (transfusion of whole blood or packed cells in $\mathrm{ml} / \mathrm{kg}$ was calculated from the records and then number of units), type of blood transfused (whole blood or packed cells; leucoreduced or non-leucoreduced blood), transfusion interval, status of splenectomy and detailed clinical evaluation. Investigations done were - peripheral smear, to look for evidence of any significant hemolysis, a screening test to detect the presence of antibodies directed against red blood cell antigens belong to the Rh (D, C, E, C, e, Cw ), Kell (K, k), Duffy (Fya, Fyb),Kidd (JkaJkb), Lewis (Lea, Leb), P, M NS (M, N, S, S), Lutheran (Lua, Lub) and Xg blood group systems. . Antibody screening is done in the standard immunohematology lab which also participates in EQAS (external quality assessment scheme) program in immunohematology and follows the AABB (American Association of Blood Banking) guidelines for immunohematology testing.

A commercially available 3 cell antigen panel was used for the antibody screening procedure where $25 \mu \mathrm{L}$ of the patient's serum was mixed with50 $\mu$ Lred cells using low ionic strength saline (LISS) Coombs gel card. The cards were incubated at 37 degree $\mathrm{C}$ for $15 \mathrm{~min}$ and then centrifuged for 10 minutes. Look for agglutination. If antibody screening with the 3-cell antigen panel was positive, an extended 11-cell antigen panel was used for antibody identification in LISS.
A polyspecific direct antiglobulin test was performed on all patients using $0.8 \%$ patient's red cell suspension and LISS Coombsgel cards.

\section{Results}

A total of 55 transfusion dependent $\beta$ thalassemics were included in this study out of which 30 (54.55\%) were males and $25(45.45 \%)$ females with a male to female ratio of $1.2: 1$.

(Table 1). M ean age of patients included in the study was 8.23 years (age range: 6 months -16 years).

M ean weight and height of these patients were $20.96 \pm$ $7.343 \mathrm{Kg}$ and $117.34 \pm 17.59 \mathrm{~cm}$ respectively. All the patients were receiving non leukoreduced packed red cell transfusion at an interval of 2-4 weeks. Twenty eight patients $(50.9 \%)$ have been started on regular transfusion at before or at 1year of age. Four(7.27\%) patients were of blood group $A, 4(7.27 \%)$ were blood group $A B, 18(32.73 \%)$ were blood group B and 29(52.73\%) were blood group 0. Fifty one $(92.7 \%)$ patients were of Rh positive while 4 (7.3\%) were of Rh negative blood group.

Total number of units of blood transfused ranged from 5units to 200 units (mean: 60.82 units).

Blood transfusion requirement during the previous year ranged from $102 \mathrm{ml} / \mathrm{kg} / \mathrm{yr}$ to $222 \mathrm{ml} / \mathrm{kg} / \mathrm{yr}$ (mean of $167.44 \mathrm{ml} / \mathrm{kg} / \mathrm{yr})$. On peripheral smear examination, 52 $(94.5 \%)$ patients showed features of thalassemia and $3(5.5 \%)$ were normal. The children with thalassemia who were adequately transfused have normal peripheral smear as ineffective erythropoiesis is suppressed. None of the peripheral smears were showing any features of significant hemolysis due to alloimmunization or autoimmunization.

None of the children were splenectomised.

\section{Red Cell Alloantibodies}

Out of 55 patients one patient developed alloantibody which was anti-K. Details of antibodies which were screened has been shown in Table 2. Transfusion details of the patient who has developed alloimmunisation has been mentioned in Table 3. All 55 patients were negative for Direct Coomb's Test. 


\section{Discussion}

The development of red cell antibodies (both alloantibodies and autoantibodies) occurs in a variable number of multiply transfused thalassemia major patients. In majority of them, these antibodies are non-hemolytic; however, in some, they may be hemolytic. Fifty five patients were included in this study. These patients were transfused with nonleukoreduced $\mathrm{ABO}$ and $\mathrm{RhD}$ antigen matched blood. In this study we found an alloimmunization rate of $1.8 \%$ (one patient out of 55 , who was positive for anti-K antibody) in beta thalassemics who were receiving regular nonleukoreduced packed red blood cell transfusion. This incidence is very low when compared to the various studies conducted worldwide.

Very few studies regarding alloantibody formation have been done so far in India. From the available literature, frequency of red cell alloimmunization ranges from 3.79\% to $18.8 \%$ in India. There is less disparity between the blood donor and patient population in- terms of ethnicity and hence the antigen status. This may be the reason for the lower alloimmunization rate in our study population. However we have not studied the frequency of minor red cell antigens in this population and that is the limitation of the study.

Some international reports showed wide variation in incidence of alloimmunisation following regular transfusion in thalassemics like $22.6 \%$ in a study by Spanos et al (9), $11 \%$ in a study by Coles(10) et al, Sirchia et al reported 5.2\%(11), and Michail Merianou reported a frequency rate of $23.43 \%(12)$. Ameen et al in a study in Kuwait showed a higher frequency (30\%) (13). M ost of the available literature is from south east Asia and M editeranean countries for the review as more reaearch is being done there.

\begin{tabular}{|l|c|c|c|l|}
\hline Study, Year and Place & $\begin{array}{c}\text { Number of } \\
\text { patients }\end{array}$ & Autoantibodies & Alloantibodies & Comments \\
\hline Karimi et al, 2006(14) & 711 & $1.7 \%$ & $5.3 \%$ & $\begin{array}{l}\text { Anti-Kell (50\%) >Anti-Rh (D) (15.8\%) >Anti-Rh (E) } \\
(10.5 \%)\end{array}$ \\
\hline Noor Haslina et al, 2006(15) & 58 & 1.7 & 8.6 & anti-E, anti-C, anti-K, anti-J ka, anti-N and anti-S \\
\hline Wang LY et al, 2006(5) & 30 & - & 37 & $\begin{array}{l}\text { anti-E, two of anti-E +C, two of anti-'M i(a)', one of } \\
\text { anti-'M i(a)' +E, one of anti-D and one of anti-S }\end{array}$ \\
\hline Bilwani et al, 2005(16) & 97 & - & 9.2 & $\begin{array}{l}\text { 3 anti-K, anti-D, anti-E, anti-C, 2 nonspecific } \\
\text { antibody }\end{array}$ \\
\hline Bhatti et al, 2004(17) & 161 & 1.87 & 4.97 & one example each of anti-K, anti-Jsb and anti-Jka \\
\hline Singer et al, 2000(1) & 64 & 25 & 22 & $\begin{array}{l}\text { Anti K, C, S and Fyb accounted for 38\% of the } \\
\text { alloantibodies }\end{array}$ \\
\hline Ameen et al, 2003 & 190 & 11 & 30 & 72\% had anti-Kell, anti-E in 11\% \\
\hline Choudhari et al , 2011 & 32 & 0 & $18.8 \%$ & $\begin{array}{l}\text { Anti E (42.9\%) and anti c (28.6\%) and anti Le and } \\
\text { anti Jk (14.3\%) }\end{array}$ \\
\hline Present study & 55 & 0 & $1.8 \%$ & Anti K \\
\hline
\end{tabular}

Michail et al reported alloimmunization in two groups of children. One was the better-matched group which comprised of children who received blood matched for(compatible with) ABO, CC, Ee, D and K antigens while the usual-match group received blood compatible with $A B O$ and RhD antigen. They also found that the overall frequency of alloimmunization between the usual-match and better- match group was not statistically significant (12).

The factors responsible for high rate of alloimmunization in thalassemics are largely unknown. Various authors have observed a lower rate of alloimmunization in patients in whom transfusion was initiated at an early age. Spanos et al and Michail Merianou $V$ et al have shown that alloimmunization rate was significantly lower in patients who started transfusion therapy before three years of age as compared to those who were started on transfusion later $(9,12)$. Singer et al. reported a higher incidence of alloimmunisation among thalassemics who were splenectomised which was attributed to the absence of an 
efficient filtering of damaged or senescent red cells which may explore new antigens(1). Further, the total number of transfusions is also expected to have an effect on frequency of alloimmunisation (18).

Even though some earlier studies have shown some correlation between development of red cell alloimmunisation and factors like age at initiation of transfusion, splenectomy status, type of blood product transfused and number of units of blood transfused, in this study we were not able to analyze such correlation in view of the low incidence.

Table - 1 : age distribution of the children included in the study

\begin{tabular}{|l|c|c|}
\hline & Frequency & Percent \\
\hline$<=5$ YRS & 17 & 31 \\
\hline 5 T0 10 YRS & 19 & 34.5 \\
\hline$>$ 10 YRS & 19 & 34.5 \\
\hline Total & 55 & 100.0 \\
\hline
\end{tabular}

Table 2 : Antibodies in screening panel

\begin{tabular}{|l|c|}
\hline Antibodies & No of positive cases \\
\hline Anti-D, Anti-C, Anti-E, Anti-C, Anti-e, & - \\
Anti-f, Anti-Cw, Anti-V & \\
\hline $\begin{array}{l}\text { Anti-K, Anti-k, Anti-Kpa, Anti-Kpb, } \\
\text { Anti-Jsa, Anti-Jsb }\end{array}$ & One (Anti-K) \\
\hline Anti-Fya, Anti-Fyb & - \\
\hline Anti-Jka, Anti-Jkb & - \\
\hline Anti-Xga & - \\
\hline Anti-Lea, Anti-Leb & - \\
\hline Anti-P1 & - \\
\hline Anti-S, Anti-S, Anti-M, Anti-N & - \\
\hline Anti-Lua, Anti-Lub & - \\
\hline
\end{tabular}

\section{References:}

1. Singer ST, Wu V, Mignacca R, Kuypers FA, Morel P, Vichinsky EP. Alloimmunization and erythrocyte autoimmunization in transfusiondependent thalassemia patients of predominantly Asian descent. Blood 2000; 96: 3369-3373.

2. Pahuja S, Pujani M , Gupta GK, Chandra J and Jain M . Alloimmunization and red cell autoimmunization in multitransfused thalassemics of Indian origin. Hematology 2010; vol 15; 3; 174-177.

3. Jolly JG, Agnihothri SK, Choudhury N, Gupta D. Evaluation of hemotherapy in thalassemias. Journal of Indian M ed Assoc 1992; 90: 7-9.

4. Surg CDR CN Chaudhari. Red Cell Alloantibodies in Multiple Transfused Thalassaemia Patients. MJAFI 2011; 67 : 34-37

5. Wang $L Y$, Liang DC, Liu HC, Chang FC, Wang CL, Chan YS, Lin M. Alloimmunization among patients with transfusion-dependent thalassemia in Thaiwan. Transfus M ed. 2006 Jun; 16(3):200-3.

6. Kruatrachu M, Sirisinha S, Pacharee $P$, Chandarayingyong D. An association between thalassemia and autoimmune haemolytic anemia (AlHA). Scand J Haematol. 1980;25:259-263.

\section{Conclusions}

Frequency of red cell alloimmunization in this study was found to be $1.8 \%$. None of the patients developed red cell autoimmunization. In most of the hospitals across our country, blood is provided to these children after ABO-Rh grouping and IAT cross-match and other antigens are not tested for. Since the development of alloantibodies in multi transfused thalassemics is a well recognized phenomenon and most of the common alloantibodies being directed against the Rh, Kell, Duffy and Kidd blood group systems, it would be ideal if phenotypically matched blood (for at least for Rh, Kell, Duffy and Kidd) can be provided to these patients who are receiving chronic blood transfusions.

Table - 3 : Details of patient who developed alloantibody

\begin{tabular}{|l|l|}
\hline Age & $7 \mathrm{yrs}$ \\
\hline Gender & Male \\
\hline ABO, Rh grouping & "A" negative \\
\hline Age at initiation of transfusion & $1 \mathrm{yr} 6$ months \\
\hline $\begin{array}{l}\text { Volume of blood transfused } \\
\text { during last one year }\end{array}$ & $180 \mathrm{ml} / \mathrm{kg} / \mathrm{yr}$ \\
\hline No of units transfused & 35 units \\
\hline Splenectomy & No \\
\hline Antibody specificity & Anti-K antibody \\
\hline Direct Coomb's Test & Negative \\
\hline Peripheral smear & RBC: Normocytic \\
& Normochromic \\
& WBC: Total count-normal \\
& No evidence of significant \\
& hemolysis \\
\hline
\end{tabular}

7. Argiolu F, Diana G, Arnone M, Batzella M G, Piras P, Cao A. High dose intravenous immunoglobulin in the management of autoimmune hemolytic anemia complicating thalassemia major. Acta Haemaol 1990,83:65-68.

8. P. Cianciulli, F. Sorrentino, L. Morino, A. Massa, G. L. Sergiacomi, V. Donato, S. Amadori . Radiotherapy combined with erythropoietin for the treatment of extramedullary hematopoiesis in an alloimmunized patient with thalassemia intermedia. Ann Hematol. 1996;73:379-381.

9. Spanos T, Karageorga M, Ladis V, Peristeri J, Hatziliami A, Kattamis C Red cell alloantibodies in patients with thalassemia. Vox Sang. 1990;58:50-55

10. Coles SM, Klein HG, Holland PV. Alloimmunization in two multitransfused patient populations. Transfusion 1981;21:462-466.

11. Sirchia G, Zanella A, Parravicini A, M orelati F, Rebulla P, M asera G. Red cell alloantibodies in thalassemia major. Results of an Italian cooperative study. Transfusion. 1985; 25:110-2

12. Michail-Merianou V, Pamphili-Panousopaulou L, Piperi-Lowes L, Pelegrinis E, Karaklis A. Alloimmunization to red cell antigens in 
thalassemia: comparative study of usual versus better match transfusion programmes. Vox Sang. 1987;52:95-98.

13. Ameen R, Al-Shemmari S, Al-Humood S, Chowdhury RI, Al-Eyaadi O, AlBashir A. RBC alloimmunization and auto immunization among transfusion-dependent Arab thalassemia patients. Transfusion 2003; 43: 1604-1610.

14. Karimi M, Nikrooz P, Kashef S, Jamalian N,Davatolhagh Z. RBC alloimmunization in blood transfusion-dependent beta-thalassemia patients in southern Iran. Int J Lab Hematol. 2007 Oct;29(5):321-6.

15. Noor Haslina MN, Ariffin N, Illuni Hayati I, Rosline H. Red cell immunization in multiply transfused Malay thalassemic patients.
Southeast Asian J Trop M ed Public Health. 2006 Sep;37(5):1015-20.

16. Bilwani F, Kakepoto GN, Adil SN, Usman M, Hassan F, Kurshid M. Frequency of irregular red cell alloantibodies in patients with thalassemia major: a bicenter study. I Pak Med Assoc. 2005;55(12):563-5.

17. Bhatti FA, Salamat N, Nadeem A, Shabbir N. Red cell immunization in beta Thalassemia major. J Coll Physicians Surg Pak. 2004;14(11):657-60.

18. WF Rosse, D Gallagher, TR Kinney, O Castro, H Dosik, J M oohr, W Wang and PS Levy. Transfusion and Alloimmunization in Sickle cell disease. Blood. 1990; 76: 1431-1437 